\title{
3112 非拘束モニタリングにもとづく追突防止支援と過信抑制インタフェース
}

\section{Towards Socially Acceptable Forward Vehicle Collision Avoidance: Adaptive Autonomy via Non-intrusive Driver-monitoring}

\author{
伊藤 誠・筑波大学
}

Makoto Itoh, University of Tsukuba

Key Words: Rear-end collisions, Prevention, Non-intrusive monitoring, Over-trust in automation, Complacency

\section{論文要旨}

This paper shows an overview of a research project on socially acceptable forward vehicle collision avoidance. The aim of this project is to develop a framework and methods for supporting "prevention" of an imminent rear-end collision. Basic ideas in this project are: (1) multi-layered support via non-intrusive driver monitoring is necessary and effective for managing driver's commitment to the driving, (2) some type of over-trust in automation may be reduced or avoidable by supporting driver's understanding of systems' functions and their limit via an appropriate human-interface.

\section{1. 背景}

日本では, 交通事故による死亡者数は減少傾向にあるもの の，事故件数自体は年々増加しており，安全対策の開発・普 及が急務となっている. 交通安全に対する工学的なアプロー チとしての先進安全自動車プロジエクトでは, 運転行動にお ける「認知・判断・操作」のうちの「操作」の支援を「運転 負荷軽減」と「事故回避支援」にわけて考え，すでに，運転 負荷軽減においてはアダプティブクルーズコントロール

(ACC) システムなど，事故回避支援においてはプリクラッ シュセーフティ（PCS）システムなど, が実用化されている.

操作支援では，システムに対するドライバの過信が懸念さ れ，ドライバがシステムに過度な期待を抱かないように「配 慮」することがメーカに求められている.そこで, 現状では, 事故の危険性が間近に迫っているときに事故を回避しよう とする「操作を伴う」支援は行わないことになっている，そ の結果，たとえば，ACCにおいては「最大減速度 $0.25 \mathrm{G} 」 に$ とどめられ，ACC は追突防止の支援としては機能しない。 また，PCS は，事故回避支援といいながらも，実際に作動す るのは「衝突が避けられない」ときに限定される。こうした 考え方は日本のみではなく，世界的に同様の傾向がみられる。

しかし，こうした「配慮」に基づいたデザインが，支援シ ステムのあるべき最終形であるかといえば, 答えは必ずしも 肯定的ではない，事故件数を抜本的に減少させることを第一 に考えれば,「衝突が避けられない」状況に至る前の積極的 な減速制御も必要になる場面がある. システムへのドライバ の過信や依存を抑制しつつ, 追突防止を支援するシステムの 実現を目指すことが課題となっている。

\section{2. 研究プロジェクト}

日本における運転支援システムの研究開発は，良くも悪 くも実用志向で進められてきた．今の技術でできることは何 か，という視点が常にあり，欧米に比しても実用化の進展は 早いといえる.これにより，運転支援システムが社会に徐々 に浸透し，社会的に受け入れられる下地を形成しつつあるこ とは間違いない。一方で，実用に「落とし込む」ために支援 システムが ACC,PCS というようにいくつかの独立のシステ ムとしてある意味で「小さくまとまって」おり，ACC と PCS との間にギャップ（ミッシングリンクというべきか）が存在 している．これに対し，追突リスクを総合的にマネジメント するという視点に立った安全運転支援システムのあり方を
検討していくことも必要である。

現在, 文部科学省科学研究費補助金基盤研究 (A)により, 表題の研究活動が平成 18 年度から 20 年度までの 3 力年計画 で推進されている（研究代表者 伊藤誠）。この研究は, 従 来の「運転負荷軽減」と「衝突被害軽減」とのギャップを埋 める追突防止支援を行うことがいかにして可能であるかを 探究しようとするものである。

本研究では，一般車両が高速道路で先行車に追従中である 場合を対象とする. 追突防此支援に対するドライバの過信や 過依存を抑えつつ, 必要ならば追突事故を防止するための制 御介入も行うことを可能にすることを目指す．単に，追突の 危険が高まっているときに機械が操作に介入する，というこ とだけであるならば，既存の技術でもある程度可能であり， ドライバの過信や過依存を防ぐための機構が重要になる。

ここでは，2つの考え方に立脚する．ひとつは，多層支援 の考え方(1)である.いかなる場合でもシステムが事故回避操 作に介入するのでは，システムに対するドライバの依存を促 しかねない.ドライバの運転への注意をモニタリングし，必 要に応じて状況認識の強化支援や警報の提示を行い, ドライ バが最大限の努力を図っていても対応が遅れた場合など，真 に必要な場面においてシステムが安全制御を行うロジック を構築する(Fig. 1)

\section{Multi-layered support}

\begin{tabular}{|c|c|c|}
\hline 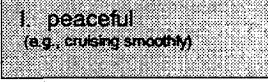 & 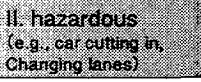 & (1) 19 \\
\hline \multicolumn{2}{|l|}{$\mathrm{ACC}$} & PCS \\
\hline $\begin{array}{l}\text { (a) Cognitive distraction } \\
\text { (b) Biomechanical } \\
\text { distraction }\end{array}$ & $\begin{array}{l}\text { (d) falure in } \\
\text { preparation } \\
\text { (e) Ineppropriate } \\
\text { intention }\end{array}$ & $\begin{array}{l}\text { (e) failure or delay in } \\
\text { safety control actions }\end{array}$ \\
\hline $\begin{array}{l}\text { Support awareness of own } \\
\text { state, } \\
\text { task re-allocation }\end{array}$ & $\begin{array}{l}\text { Support level I SA } \\
\text { on traffic }\end{array}$ & $\begin{array}{l}\text { Support levels } 2.3 \text { SA } \\
\text { on traficic, or } \\
\text { reminding necessary } \\
\text { actions }\end{array}$ \\
\hline $\begin{array}{l}\text { System engaged, } \\
\text { Get ready }\end{array}$ & Envelope protection & $\begin{array}{l}\text { system-initiated } \\
\text { safety control in } \\
\text { emergency }\end{array}$ \\
\hline
\end{tabular}

Fig. 1 Multi-layered support 
実用に酎えうるシステムを構築することを視野に入れる と, ドライバの心的状態のモニタリングは, 非拘束に行える ものでなければならない，すでにいくつかの非拘束的センサ によりドライバの心的状態を推定できる場合があることが わかってきている(2)。ただし，一般車両での利用を想定する とき,センシング機構は低コストで実現できる必要があるこ とから, 本研究では, 少数のセンサによる非拘束モニタリン グ技術を開発する

もうひとつの考え方は, システムの機能やその限界を誤解 するという意味で過信を論ずるならば，そのような過信は

「誰にでも起こりうる」ものである(3)ということである．逆 に言うと, インタフェースのデザイン次第で, 過信抑制の余 地がある.そこで, 本研究でも, システムの動作理解を促し たり，ドライバが即座に対応しなければならない状況である ことの理解を支援する, 機能理解・状況認識の支援インタフ エースの開発に取り組む。なお，一般車両を運転する場合， ドライバや交通状況によってはマニュアル運転を選択する ことも十分にありうる.マニュアル走行中と ACC 使用中と では, 先行車減速などの事象が発生したときの行為系列が一 致するとは限らないことから, 状況認識支援と警報のデザイ ンを ACC の使用の有無によってどのように変えるべきかを 明らかにすることも狙う。

\section{3. 研究体制}

本研究では, 大きく 4 つの項目にわけて研究を進めている.

（1）ドライバ心的状態の評価に有用な非拘束運転行動観測 技術の開発

（2）運転負荷軽減システム使用時の状況認識強化支援

（3）マニュアル走行時の状況認識強化支援

（4）負荷軽隇から追突防止へのスムーズな接続のためのド ライバ心的状態に応じた制御アルゴリズム開発

本研究プロジエクトの研究相関図を図 1 に示す.

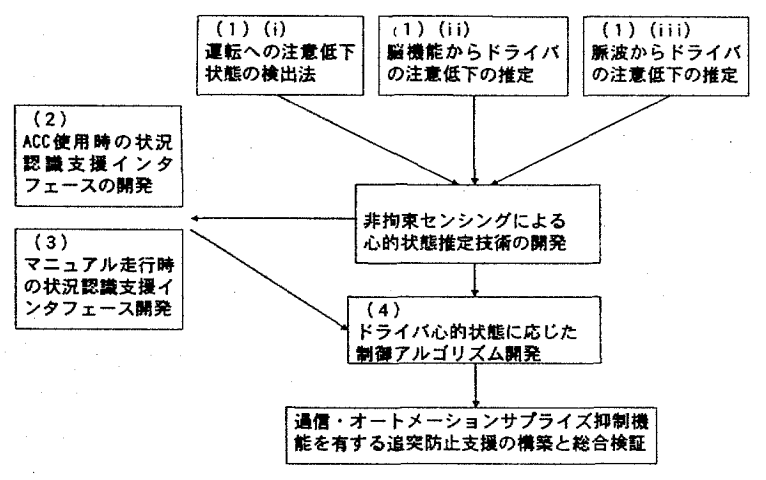

Fig. 2 Structure of the research project

現在，（1）-（3）の各項目が進行中である.

（1）(i) 顔表面の温度，脈波，視線，操觗角など，非拘束 な方法によって計測可能な指標によって運転への注意が踈 外された状態の検出技術の開発を行っている. Itoh, Inagaki ${ }^{(2)}$ にこれまでの成果がまとめられている．また，運転行動や動 作から，ドライバの姿勢や動きが圧力となって現れる「着座 接触圧」を用いる方法の開発にも取り組んでいる(4).

(1) (ii)fNIRS 計測装置を用いて自動車運転中の脳機能計測 を行い, 運転中の心的状態の変化に伴って生じる現象を分 類・整理している(5). （1）(iii）脈波計測装置を用いて，自動車運転中の心的状態 の変化に伴って脈波に生じる現象を分類・整理する(6). 脈波 は，着座接触圧から計測したり，ステアリングホイールに埋 設したセンサから計測する技術もあり，生理的指標ではある が非拘束計測手法としても有望である. しかし，個人差が大 きいこともしられており(たとえば，Itoh，Inagaki $\left.{ }^{(2)}\right)$ ，どの 程度影響が現れやすいかを統計的に明らかにすることが課 題になっている.

（2）ACC による制御中に交通状況が定常的でなくなった 場合にできるだけ早期に安全な状態を確保するために, 状況 認識支援の方法を検討する。具体的には，ACC が作動中で あることを考慮に入れて，周囲への注意を阻害することなく， ACC の減速が限界に達しつつあることをドライバに伝える 方法を開発する(一例は, 伊藤(7)で議論している).

（3）ドライバの認知・判断・操作の過程を, 衝突回避のブ レ一キ操作時間を定量的に評価することによって明らかに する.さらに，上記の解析に基づいたドライバのブレーキ操 作の過程と警報タイミングとの関係から，ドライバの警報に 対する認識や期待の仕方がどのように変化するかを解明す る(8,9).

\section{4. 本 OSの组い}

本オーガナイズドセッションは, 研究期間のうち約半分を 経過した時点での本研究プロジェクトの進渉状況を報告す ることによって，現時点で還元できる成果は積極的に公表す るとともに，本研究がカバーする領域に興味をお持ちの各位 からご批判いただき, 今後の研究推進に役立てたいと思って 企画したものである. 率直なご意見を賜ることができれば幸 いである.

謝辞

本研究は，文部科学省科学研究費補助金 基盤研究(A) 18201031 の援助を受けている．記して謝意を表する。

参考文献

（1）稲垣敏之，「状況・意図理解によるリスクの発見と回避」, ヒューマンインタフェース学会研究報告集, Vol. 7, No. 1, pp. 13-18, 2005

(2) M. Itoh, T. Inagaki: "Cognitive distraction due to mental overload and its detection via a driver-adaptive sensor fusion approach", Proc. IFAC-HMS, CD-ROM, 6 pages, 2007

（3）伊藤誠：「信頼されすぎない高信頼度なシステムへ」, 日本信頼性学会誌, Vol. 25, No. 4, pp. 354-360, 2003.

（4）伊藤,他, 着座接触圧にもとづくドライバーの動作推定, 自動車技術会 2007 年秋季大会学術講演会（発表予定）

（5）柳沼, 他，自動車運転時における前頭連合野の高次脳機 能計測, 日本機械学会第 16 回 交通・物流部門大会予稿 集

（6）鈴木，岡田，指尖脈波のゆらぎ解析によるドライバ心理 状態の推定, 日本機械学会第 16 回 交通・物流部門大会 予稿集

（7）伊藤誠：「減速度の準実時間表示による ACC 機能限界の 理解支援」，計測自動制御学会システム・情報部門学術 講演会 2007 (発表予定)

（8）伊藤，稻垣，状況適応的な運転行動適合型追突警報，日 本機械学会第 16 回 交通・物流部門大会予稿集

（9）安部, 伊藤, ドライバの運転操作にもとづく追突警報夕 イミングとドライバ反応，日本機械学会第 16 回 交通・ 物流部門大会予稿集 